\title{
HYPOTHESIS
}

\section{Did malaria select for primary adult lactase deficiency?}

\author{
B Anderson, C Vullo
}

$\beta$ galactosidase is the intestinal enzyme that catalyses the digestion of lactose in milk. It is thought to be controlled by an autosomal gene with a dominant lactase persistence allele, and a recessive lactase restriction allele which is responsible for 'primary adult lactase deficiency'. ${ }^{1-6}$ At birth lactase activity is high in almost all mammals but it declines to low levels after weaning in most of the animal kingdom and slowly declines between two and six years in most humans. ${ }^{5-9}$

It has only been realised in the last 20 years that there is this high frequency of low lactase activity $(60-100 \%)$ in most of the adult world population ${ }^{10}$ - found in most native populations of tropical and subtropical zones such as Africa, east and south Asia, the Pacific, Australia, and the Mediterranean countries, and in American Indians and Eskimos who migrated from east Asia 40000 years ago. In all these peoples there is a history of drinking little or no unfermented milk.

In contrast, lactase activity remains high in most adults in northwest Europe, and in nomads coming from the African and Asian deserts. ${ }^{6}$ These people have in common a long history of milk drinking. This suggested the geographic evolutionary hypothesis of Simoons to explain the world distribution. ${ }^{81011}$

Simoons' hypothesis proposes that because most adult humans and mammalian animals have low lactase activity, lactase persistence after infancy must be the 'unusual' condition and lactase restriction the earliest phenotype; and that with otherwise marginal nutrition a mutant lactase persistence phenotype in adulthood would have given a survival advantage to milk drinkers. It is suggested therefore that in the past 10000 years a natural selection for the lactase persistence phenotype took place in parts of the world where milk drinking had become a habit, such as in northwest Europe and the deserts.

There have been several other hypotheses $5681012-16$ all of which presuppose that the earliest phenotype was low lactase activity, but Kretchmer ${ }^{17}$ pointed out that this was a 'predjudice rather than a proven fact'. Evidence is against enzyme induction by lactose $^{11}$ and the most commonly accepted hypothesis is that of Simoons, though there have been some queries. ${ }^{615} 18-20$ In particular, Nei and Saitou ${ }^{20}$ consider that the lactase persistence phenotype is much older than was suggested, as its presence in virtually all races today suggests that it existed before the separation of the important three major races more than 100000 years ago and long before milk drinking existed. High lactase activity would have permitted the adoption of the milk drinking habit although in turn it could then have given an advantage for survival.

The suggested antiquity of the lactase persistence phenotype has encouraged us to suggest that another explanation for the very high frequency of primary adult lactase deficiency in the world today might be a selection by malaria commencing very early in prehistoric times for a mutant lactase restriction phenotype. Bruce-Chwatt ${ }^{21} 22$ states that it is generally agreed that the host-parasite relationship originated in tropical Africa at the dawn of humanity; that in the neolithic revolution 10000 years ago the infection was well established in Mesopotamia, India, China, and the Nile Valley, and on the Mediterranean shores; and that from these five main foci it spread through the tropical and subtropical world. In about the 15th century malaria appeared in northern Europe for a few centuries but it seems that it was not usually the falciparum strain causing fatal malaria.

The idea of malaria selection arose because the areas where lactase deficiency predominates compare closely with those where falciparum malaria was always endemic (Figure) ${ }^{2122}$; and where thalassaemia, G6PD deficiency, and sickle cell disease are believed to have been selected for by malaria. ${ }^{23}$ The absence of malaria in the African and Arabian deserts could explain why in these people high lactase activity predominates.

Lactase deficiency causes intestinal problems resulting from undigested lactose from milk, which discourages milk drinking, ${ }^{101124-26}$ the richest source of riboflavin. Therefore, with otherwise marginal nutrition a mild riboflavin deficiency might develop. There is increasing evidence in vitro and in vivo, that multiplication of malaria parasites is inhibited in flavin deficient red cells ${ }^{27-36}$ and furthermore, is also inhibited in red cells with a deficiency, induced by nitrosoureas, of the flavin adenine dinucleotide dependent glutathione reductase. ${ }^{37} 38$ Dutta $^{36}$ believes that the malaria parasite is sensitive to a mild riboflavin deficiency, which is tolerated by the human host. In the three in vivo studies in humans lower red cell parasitaemia related to low riboflavin was shown. ${ }^{31} 3334$ Flavin 

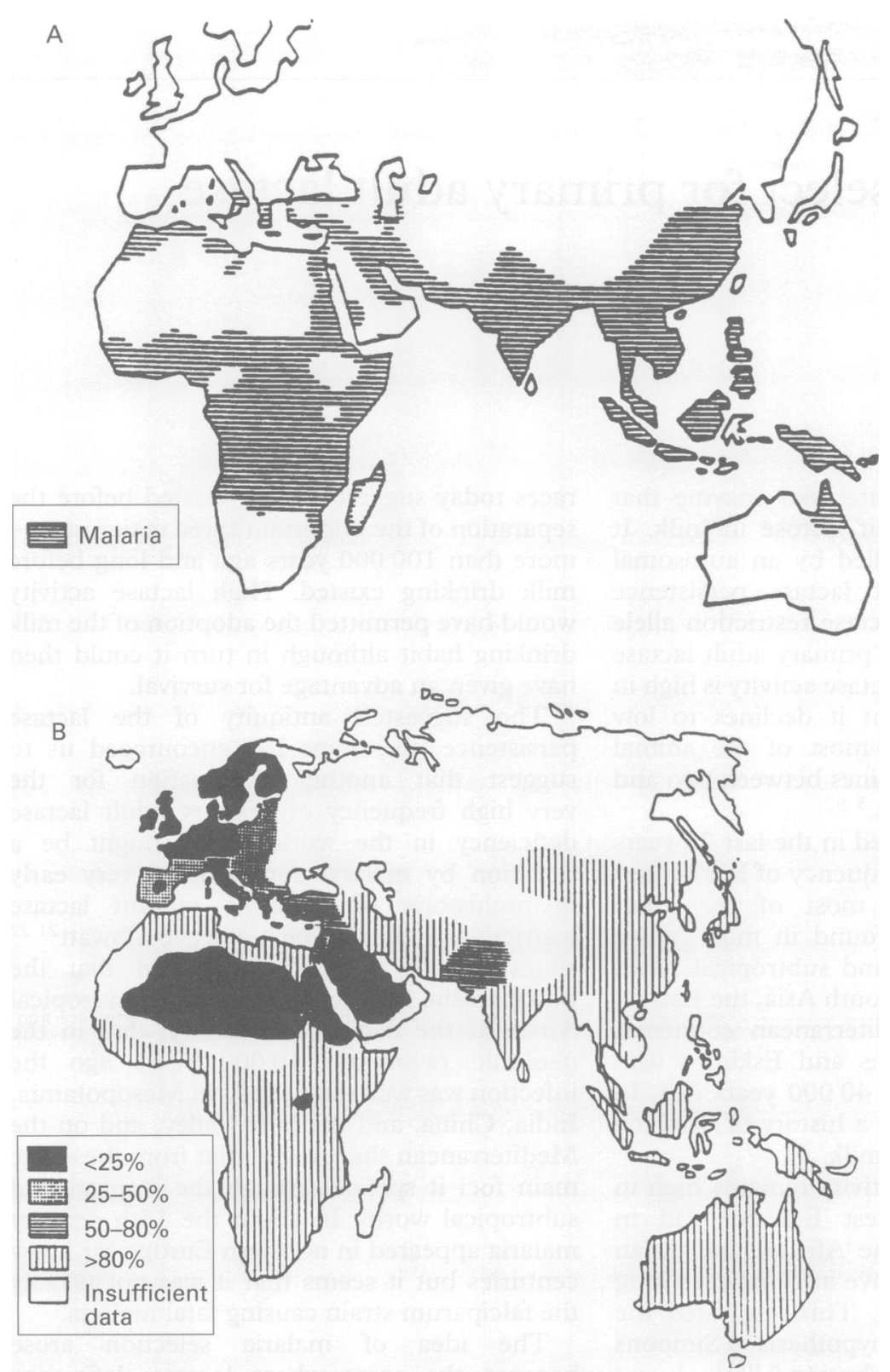

Geographical distribution in the Old World of $(A) \mathrm{P}$ falciparum malaria endemic over the centuries and still endemic in most areas and $(B)$ the percentage of low lactase activity in the native populations. These maps are adapted from those contained in references ${ }^{21}$ and 6 respectively. This figure is reprinted with permission from McGraw-Hill (ref 6) and World Health Organisation (ref 21).

deficient red cells may not prevent malaria but could lead to less fatality.

There is also evidence that malaria selected for a genetically controlled flavin deficient red cell, probably due to slow red cell metabolism of riboflavin to flavin mononucleotide and flavin adenine dinucleotide which affects the flavin status of red cells but not other tissues. 3040 If this accompanied low lactase activity protection against malaria would be even greater.

If selection occurred in adult life it could only have done so if milk drinking existed where now it is virtually absent - the first convincing evidence of milking was in north Africa between 4000 and $3000 \mathrm{BC}^{8}$ though it probably existed earlier. ${ }^{1011}$ On the other hand, if selection occurred mainly in infancy during late breast feeding and weaning at the time of the decline in lactase activity, it could have commenced independently of the milking habit and as far back as malaria existed.
During the first three months of life an infant is thought to be protected against malaria by passive transfer of maternal antibodies, ${ }^{41}$ but it has been known since the time of Horace that older infants are at risk for recurrent severe attacks of malaria. ${ }^{41} 42 \mathrm{An}$ indication that selection by malaria occurred in infancy could be that lactase activity declines considerably earlier in many of the populations in malarial areas than elsewhere ${ }^{5916}$; for example, if activity declines in Finns it does so in the late teens whereas it declines between one month and two years in most Thai infants, in whom there is known to be a high incidence of 'weanling diarrhoea' ${ }^{43}$ It was suggested that an intolerance seen in Zambia to mother's milk towards the end of breast feeding was caused by the early development of lactase deficiency ${ }^{44}$ and that a progressive lactase deficiency in young mammals controls the time and rate of weaning. ${ }^{45}$

As the lactose content of human milk is high $^{5}$ the decline in lactase activity in infants probably causes excessive intestinal accumulation of undigested lactose. A consequent reduction in breast feeding, without supplementation, could lead to a gradual development of mild riboflavin deficiency and hence protection against severe malaria.

In summary, we propose that the lactase persistence phenotype was the 'wild type' that permitted prolonged breast feeding, and that a mutant lactase restriction phenotype was selected for by malaria, occurring mainly during late breast feeding and weaning and starting as early as Paleolithic times when malaria originated in tropical Africa. The rationale for the selection is that the decline in lactase activity leading to lactose intolerance discouraged breast feeding, a rich source of riboflavin. With inadequate alternate nutrition mild riboflavin deficiency developed, which could be tolerated by the human host but red cell multiplication of malaria parasites was inhibited and severe and fatal malaria prevented. This protection would have been greater if associated with an inherited slow red cell metabolism of riboflavin, also selected for by malaria. Finally, the variable timing of switching off of lactase activity and very early decline found in most malarial areas could have resulted from malaria selecting for a progressively earlier switching off.

We hope that this malaria hypothesis will stimulate studies in different parts of the world into the interrelations between the distribution of lactase deficiency and the history of milk drinking, red cell riboflavin deficiency, and malaria.

We would like to thank Professor Italo Barrai, Professor Enrico Gandini, Dr Laura Del Senno, and Dr Nefertiti Sourial for their encouragement in pursuing this idea. We are particularly grateful to Dr Marco Lucci, Dr Gillian Perry, and Dr Adrian Stephens for their advice and help.

1 Cuatrecasas P, Lockwood DH, Caldwell JR. Lactase deficiency in the adult. A common occurrence. Lancet 1965; i: 14-8.

2 Bayless TM, Rosensweig NS. A radical difference in incidence of lactase deficiency. A survey of milk intolerance and lactase deficiency in healthy adult males. $\mathfrak{F} A M A$ and lactase deficient 
3 Sahi T, Isokoski M, Jussila J, Launiala $\mathrm{K}$, Pyorala $\mathrm{K}$ Recessive inheritance of adult-type lactose malabsorption. Lancet 1973; ii: 823-6.

4 Sahi T. The inheritance of selective adult-type lactose malabsorption. Scand f Gastroenterol 1974; 9 (suppl 30): $1-73$.

5 Flatz G. Genetics of lactose digestion in humans. Adv Hum Genet 1987; 16: 1-77.

6 Flatz G. The genetic polymorphism of intestinal lactase activity in adult humans. In: Scriver CR, Beaudet AL, Sly WS, Valle D, eds. The metabolic basis of inherited disease II. 6th ed. New York: McGraw-Hill, 1989: 2999-3006.

7 Blaxter KL. Lactation and the growth of the young. In: Kow SK, Cowie AT, eds. Milk: the mammary gland and its secreSK, Cowie AT, eds. Milk: the mammary gland and
tion. New York: Academic Press, 1961: 329-38.

8 Johnson JD, Kretchmer N, Simoons FJ. Lactose malabsorption: its biology and history. Adv Pediatr 1974; 21: 197-237.

9 Simoons FJ. Age of onset of lactose malabsorption Pediatrics 1980; 66: 646-8.

10 Simoons FJ. The geographic hypothesis and lactose malabsorption. A weighing of the evidence. Am $\mathcal{F}$ Dig Dis 1978; 23: $963-80$.

11 Simoons FJ. Primary adult lactose intolerance and the milking habit: a problem in biologic and cultural interrelations. II. A culture historical hypothesis. Am $\mathcal{f}$ Dig Dis tions. II. A culture

12 Simoons FJ. Primary adult lactose intolerance and the milking habit: a problem in biological and cultural interrelations. I. Review of the medical research. Am $\mathcal{F}$ Dig Dis 1969; 14: 819-36.

13 Flatz G. Rotthauwe HW. Lactose nutrition and natura selection. Lancet 1973; ii: 76-7.

14 Cook GC, Al-Torki MT. High intestinal lactase concentrations in adult Arabs in Saudi Arabia. BMF 1975; 3: 135-6.

15 Nurse GT. The importance of intestinal lactase and milk tolerance in Southern Africa. Leech Fohannesburg 1977; 47: 8-10.

16 Cook GC. Hypolactasia, geographical distribution, diagnosis, and practical significance. Crit Rev Trop Med 1984, 2: $117-39$.

17 Kretchmer N. The geography and biology of lactose digestion and malabsorption. Postgrad Med $\mathscr{f}$ 1977; 53: 65-72 18 Bayless TM. Junior, why didn't you drink your milk? Gastroenterology 1971; 60: 479-80

19 Bayoumi RAL, Flatz SD, Kuhnau W, Flatz G. Beja and Nilotes: nomadic pastoralist groups in the Sudan with opposite distributions of the adult lactase phenotypes. $A m$ f Phys Anthropol 1982; 58: 173-8.

20 Nei M, Saitou N. Genetic relationship of human populations and ethnic differences in reaction to drugs and food. In: Kalow W, Goedde HW, Agarwal DP, eds. Ethnic differences in reactions to drugs and other xenobiotics. New York: AR Liss, 1986: 21-37.

21 Bruce-Chwatt LJ. Paleogenesis and paleo-epidemiology of primate malaria. Bull WHO 1965; 32: 363-87.

22 Bruce-Chwatt LJ. History of malaria from prehistory to eradication. In: Wernsdorfer WH, McGregor IA, eds. Malaria principles and practice of malariology. Edinburgh Churchill Livingstone, 1988; 1-59.

23 Nagel RL, Roth EF, Jr. Malaria and red cell genetic defects. Blood 1989; 74: 1213-21.

24 Bedine MS, Bayless TM. Intoleralance of small amounts of lactose of individuals with low lactase levels. Gastroenterology 1973; 65: 735-43.

25 Simoons FT, Johnson JD, Kretchmer N. Perspective on milk-drinking and malabsorption of lactose. Pediatrics 1977; 59: 98-109.

26 Friedl J. Lactase deficiency: distribution, associated problems, and implications for nutritional policy. Ecol Food Nutr 1981; 11: 37-48.

27 Seeler AO, Ott WH. Effect of riboflavin deficiency on the course of Plasmodium lophurae infection in chicks fInfect Dis 1944; 75: 175-8.

28 Rama Rao R, Sirsi M. Avian malaria and B complex vitamins. II. Riboflavin. Fournal of the Indian Institute of vitamins. II. Riboflavin.

29 Kaikai P, Thurnham DI. The influence of riboflavin deficiency on Plasmodium berghei infection in rats. Trans $R$ Soc Trop Med Hyg 1983; 77: 680-6.

30 Thurnham DI, Oppenheimer SJ, Bull R. Riboflavin status and malaria in infants in Papua New Guinea. Trans $R$ Soc Trop Med Hyg 1983; 77: 423-4.

31 Oppenheimer SJ, Bull R, Thurnham DI. Riboflavin deficiency in Madang infants. $P N G M e d f(1983$; 26: $17-20$.

32 Dutta P, Pinto J, Rivlin R Antimalarial effects of riboflavin deficiency. Lancet 1985; ii: 1040-3.

33 Bates CJ, Powers HJ, Lamb WH. Antimalarial effects of riboflavin deficiency. Lancet 1986; i: 329.

34 Das BS, Das DB, Satpathy RN, Patnaik JK, Bose TK Riboflavin deficiency and severity of malaria. Eur $\mathcal{F}$ Clin Nutr 1988; 42: 277-83.

35 Dutta P, Gee M, Rivlin RS, Pinto J. Riboflavin deficiency and glutathione metabolism in rats: possible mechanisms underlying altered responses to hemolytic stimuli. $\mathfrak{f} \mathrm{Nut}$ 1988; 118: 1149-57.

36 Dutta P. Enhanced uptake and metabolism of riboflavin in erythrocytes infected with Plasmodium falciparum. Protozool 1991; 38: 479-83.

37 Zhang Y, Hempelmann E, Schirmer RH Glutathione reductase inhibitors as potential antimalarial drugs. reductase inhibitors as potential antimalarial drugs. vitro. Biochem Pharmacol 1988; 37: 855-60.

38 Zhang Y, Konig I, Schirmer RH. Glutathione reductasedeficient erythrocytes as host cells of malarial parasites. Biochem Pharmacol 1988; 37: 861-5.

39 Anderson BB, Perry GM, Vullo C. Antimalarial effects of riboflavin deficiency. Lancet 1986; i: 329.

40 Anderson BB, Giuberti M, Perry GM, Salsini G, Casadio I Vullo C. Low red blood cell glutathione reductase and pyridoxine phosphate oxidase activities not related to dietary riboflavin: selection by malaria? $\mathrm{Am} \mathcal{f}$ Clin Nutr 1993; 57: 666-672.

41 Cohen S, McGregor IA, Carrington S. Gamma-globulin and acquired immunity to human malaria. Nature 1961 , 192: 733-7.

42 Brunt CA. Malaria in ancient Italy. In: Italian manpower 225 $B C-A D$ 14. Oxford: University Press, 1971: 611-24.

43 Varavithya W, Valyasevi A, Charuchinda S. Lactose malabsorption in Thai infants. F Pediatr 1971; 78: 710-5.

44 King F. Intolerance to lactose in mother's milk? Lance 1972; ii: 335.

45 Lieberman M, Lieberman D. Lactase deficiency: a genetic mechanism which regulates the time of weaning. The American Naturalist 1978; 112: 625-39. 